\title{
Estrogen receptor-positive breast cancer molecular signatures and therapeutic potentials (Review)
}

\author{
MEI HONG ZHANG, HONG TAO MAN, XIAO DAN ZHAO, NI DONG and SHI LIANG MA \\ College of Biological Science and Biotechnology, Shenyang Agricultural University, Shenyang, Liaoning 110866, P.R. China
}

Received March 18, 2013; Accepted August 23, 2013

DOI: $10.3892 /$ br.2013.187

\begin{abstract}
In this review, the advances in the study of breast cancer molecular classifications and the molecular signatures of the luminal subtypes A and B of breast cancer were summarized. Effective clinical outcomes depend mainly on successful preclinical diagnosis and therapeutic decisions. Over the last few years, the ever-expanding investigations focusing on breast cancer diagnosis and the clinical trials have provided accumulating information on the molecular characteristics of breast cancer. Specifically, among the estrogen receptor (ER)-positive types of breast cancer, the luminal subtype A breast cancer has been shown to exhibit good clinical outcomes with endocrine therapy, whereas the luminal subtype B breast cancer represents the more complicated type, diagnostically as well as therapeutically. Furthermore, even in luminal subtype A breast cancer, the resistance to treatment has become the major limitation for endocrine-based therapy. Accumulating molecular data and further clinical trials may enable more accurate diagnostic and therapeutic decisions. The molecular signatures have emerged as a powerful tool for future diagnosis and therapeutic decisions, although currently available data are limited.
\end{abstract}

\section{Contents}

1. Introduction

2. Luminal A subtype breast cancer molecular signatures and therapeutic potentials

3. Luminal B subtype breast cancer molecular signatures and therapeutic potentials

4. Challenges and perspectives

Correspondence to: Professor Shi Liang Ma, College of Biological Science and Biotechnology, Shenyang Agricultural University, 120 Dongling Road, Shenyang, Liaoning 110866, P.R. China E-mail: msl@syau.edu.cn

Key words: breast cancer molecular subtype, estrogen receptor, molecular signature

\section{Introduction}

Breast cancer is one of the major causes of cancer-related morbidity and mortality among women worldwide (1). Breast cancers originate from the epithelial cells of the normal mammary gland. The ducts are lined with luminal epithelial cells, which give rise to the majority of breast cancers (2). As a heterogeneous disease, breast cancer encompasses a wide variety of pathological entities and this heterogeneity is reflected by the differences in cell type composition and proportions, the differences in the proliferation ability between glandular and myoepithelial cells, the proliferation of progenitor cells, the therapeutic responses and patient outcomes $(3,4)$. Breast cancer patients with the same clinical diagnostic and prognostic profiles may exhibit markedly different clinical overall outcomes and treatment responses (5), which may be due to the current breast cancer taxonomies based on the morphological groups, dividing the disease into clinical classes (6). Therefore, the clinical behavior of cancer is not solely dependent on morphology and a molecular taxonomy based on 'signature' profiles may facilitate a more accurate prediction of response to therapy and prognosis (7).

The current molecular classifications of breast cancer molecular subtypes are generally based on the gene expression profiles according to i) luminal cell-related markers, such as cytokeratins (CKs); ii) hormone receptors, such as estrogen receptor (ER), progesterone receptor (PR) and androgen receptor (AR); iii) growth factor receptors, such as human epidermal growth factor receptor (HER); iv) anti-apoptosis markers, such as Bcl-2 and $\mathrm{p} 53$; v) cell proliferation indicators, such as Ki-67 and survivin; vi) cell invasion-related factors, such as matrix metalloproteinases (MMPs) and integrins; vii) signal transduction pathway members, such as the PI3K/AKT pathway members phosphatidylinositol-3-kinase (PI3K) and AKT; viii) cell cycle control members, such as cyclins and cyclin-dependent kinases (CDKs); ix) epithelial-to-mesenchymal transition-indicating factors and regulating factors, such as cadherins and zinc-finger transcription factors Snail, Slug, Zeb1 and Twist; x) metastatic control factors; and xi) blood vessel-forming control factors (8-10). This spectrum also includes stem cell markers, tumor cell and microenvironment interacting factors and other small regulatory molecules, such as microRNAs or other non-coding RNAs. The currently established molecular classification of breast cancers distinguishes breast cancer molecular subtypes into five intrinsic subtypes: i) luminal subtype $\mathrm{A}\left(\mathrm{ER}^{+}\right.$ 
and/or $\mathrm{PR}^{+}, \mathrm{HER}^{-}$and $\left.\mathrm{CK} 8 / 18^{+}\right)$; ii) luminal subtype $\mathrm{B}\left(\mathrm{ER}^{+}\right.$ and/or $\mathrm{PR}^{+}, \mathrm{HER}^{+}$and $\mathrm{CK} 8 / 18^{+}$); iii) HER2-enriched subtype (ER ${ }^{-}$and/or $\mathrm{PR}^{-}$and $\mathrm{HER} 2^{+}$); iv) basal-like subtype [ER ${ }^{-}$and/or $\mathrm{PR}^{-}, \mathrm{HER} 2^{-}, \mathrm{CK} 5 / 6^{+}, \mathrm{CK} 14^{+}, \mathrm{CK} 17^{+}$and epithelial growth factor receptor $\left.(\mathrm{EGFR})^{+}\right]$; and $\mathrm{v}$ ) normal breast-like type (ER ${ }^{-}$and/or PR-, HER2-, CK5/6-' CK14-, CK17-, EGFR') (11-14) (Table I). Another subtype, referred to as the claudin-low subtype, was later described $(15,16)$. Furthermore, a subpopulation of the luminal A subtype with a Ki-67 proliferation index of $>14 \%$ was designated as the luminal B subtype (17). As such, the breast cancer molecular subtypes were redefined as follows: luminal A $\left(\mathrm{ER}^{+}\right.$and/or PR ${ }^{+}, \mathrm{HER} 2^{-}$and $\left.\mathrm{Ki}-67 \leq 14 \%\right)$; luminal B $\left(\mathrm{ER}^{+}\right.$ and/or PR ${ }^{+}$, HER2 ${ }^{-}$and Ki-67 >14\%); luminal B HER2/neu ${ }^{+}$ $\left(\mathrm{ER}^{+}\right.$and/or $\mathrm{PR}^{+}, \mathrm{HER} 2^{+}$and any Ki-67); HER2/neu subtype (ER ${ }^{-}$and $\mathrm{PR}^{-}, \mathrm{HER} 2 / \mathrm{neu}^{+}$and any $\left.\mathrm{Ki}-67\right)$; and triple-negative subtype (ER', PR', HER2- and any Ki-67) (18-20).

The luminal type of breast cancer tends to be morphologically well differentiated and exhibits a relatively good prognosis, whereas the ER $\mathrm{E}^{-}$tumors are poorly differentiated and exhibit a poor prognosis. The designation of the luminal type of breast cancer was derived from the finding that this type of breast cancer exhibits mRNA and protein expression of CKs 8/18 (14), which is typically associated with luminal epithelial cells, as opposed to basal cells, which express CKs 5/6. The luminal type of breast cancer was further subdivided into A and B subtypes, with the luminal B subtype exhibiting significant expression differences and worse outcomes (11). Thus, the luminal A and B subtypes are collectively referred to as the luminal type, which accounts for $65-70 \%$ of breast cancers, whereas the HER2-enriched subtype accounts for $\sim 10 \%$ of breast cancers and the basal-like subtype accounts for $10-15 \%$ (14) or, according to other sources, $19 \%$ of breast cancers $(2,5,6)$. Those molecular classification studies significantly contributed to the better understanding of the complex properties of different breast cancer types, their response to systemic treatment and their clinical outcomes, including those that respond better to endocrine treatment.

Among the different molecular subtypes of breast cancer, $\mathrm{ER}^{+}$breast cancer comprises $\sim 75 \%$ of all breast cancers (14). Thus, the ER status has become the most important discriminator of breast cancer molecular subtypes (6), resulting in primary treatment options through targeting the estrogen synthesis (aromatase inhibitors) or the ER functions (tamoxifen). The treatment effectiveness has been proven by the observation that $\mathrm{ER}^{+}$tumors were associated with hormonal responsiveness, longer relapse-free survival and overall survival compared to the ER ${ }^{-}$subtypes (21). However, resistance to hormonal therapy was reported in $30 \%$ of $\mathrm{ER}^{+}$breast cancers, whereas hormonal responsiveness was observed in 5-15\% of ER- breast cancers (22). Thus, in addition to the ER status, more detailed information associated with the molecular signature profiles and molecular networks is required for designing optimal therapeutic strategies.

\section{Luminal A subtype breast cancer molecular signatures and therapeutic potentials}

Luminal A subtype breast cancer molecular signatures. The luminal A subtype of breast cancer is characterized by the luminal-type conventional molecular signatures (ER, PR, Bcl-2 and $\mathrm{CK} 8 / 18$ ) and the luminal A subtype-specific signatures of $\mathrm{ER}^{+}$and/or $\mathrm{PR}^{+}, \mathrm{HER} 2^{-}$and $\mathrm{Ki}-67 \leq 14 \%$, which distinguishes luminal A from luminal B subtype. The recognized luminal A subtype breast cancer molecular signatures include GATA binding protein 3 (GATA-3), X-box binding protein 1 (XBP-1), forkhead box A1 (FOXA1) and ADH1B (23-26). The 5-year survival rate of luminal type A breast cancer is $95 \%$, which is the highest among the five types, with a p53 mutation rate of $13 \%$ (11).

Studies of the crosstalk between estrogen receptor $\alpha(\mathrm{ER} \alpha)$, FOXA1 and GATA-3 revealed that, in addition to the ER and PR status, FOXA1 and GATA-3 are also correlated with the luminal A subtype $(11,14,25,27)$. The interaction of FOXA1 with the cis-regulatory regions of heterochromatin enhances the binding of ER $\alpha$ to DNA (28) and is involved in controlling almost $50 \%$ of the estrogen receptor target genes $(29,30)$. The expression of FOXA1 is significantly positively correlated with the markers of good prognosis or ER-positivity (31) and FOXA1 was recently shown to be required for almost all the ER-binding events in breast cancer cells (32). The transcription factor GATA-3 was recently identified as a key factor involved in luminal cell differentiation in the mammary gland (33). The majority of breast cancers arise from the luminal epithelial cells; therefore, GATA-3 appears to regulate a set of genes involved in the differentiation and proliferation of breast cancer cells (33). Low GATA-3 expression is significantly associated with a higher histological grade, poor differentiation, positive lymph nodes, $\mathrm{ER}^{-}$and $\mathrm{PR}^{-}$status and HER2/neu overexpression, which are all indicators of poor prognosis (34). The expression of GATA-3 is strongly associated with the expression of ER $\alpha$ in breast cancer and there is increasing evidence that GATA-3 may be used as a clinical molecular signature to determine the response to hormonal therapy and to refine the prognosis of breast cancer patients $(33,35,36)$. The prognosis of the luminal A subtype breast cancer is more favorable compared to that of other subtypes $(2,6)$, which may be due to the fact that the luminal A subtype expresses high levels of GATA-3 that confer a favorable prognosis. It was previously reported that GATA-3 functions as a critical regulator of commitment and maturation of cancer cells in the luminal A epithelial lineage, i.e., the expression of GATA-3 regulates luminal differentiation (37). The anti-apoptotic marker Bcl-2 has been proven to be an independent molecular signature, alone or in combination with $\mathrm{Ki}-67$ as a marker pair, in the luminal type of breast cancer (38-42).

The 70-gene signature (MammaPrint ${ }^{\circledR}$ ) assay provides a powerful prognostic gene expression signature profile for the prediction of distant recurrence and survival of primary breast cancer, including luminal subtype A breast cancer (43). Other molecular profilings of clinically applicable gene expression-based prognostic panels, such as the Oncotype DX platform, may add more characteristics regarding the prediction of recurrence and survival and the therapeutic options of luminal A type breast cancer $(44,45)$. It was recently demonstrated that microRNA expression profiles may be a promising molecular signature for the classification of breast cancer subtypes (46). The prediction of $\mathrm{ER}^{+}$cancer clinical relapse and the sensitivity to endocrine therapy with genomic signatures, such as the PAM50 intrinsic subtyping and risk of relapse (PAM50-ROR) score, the 21-gene assay 


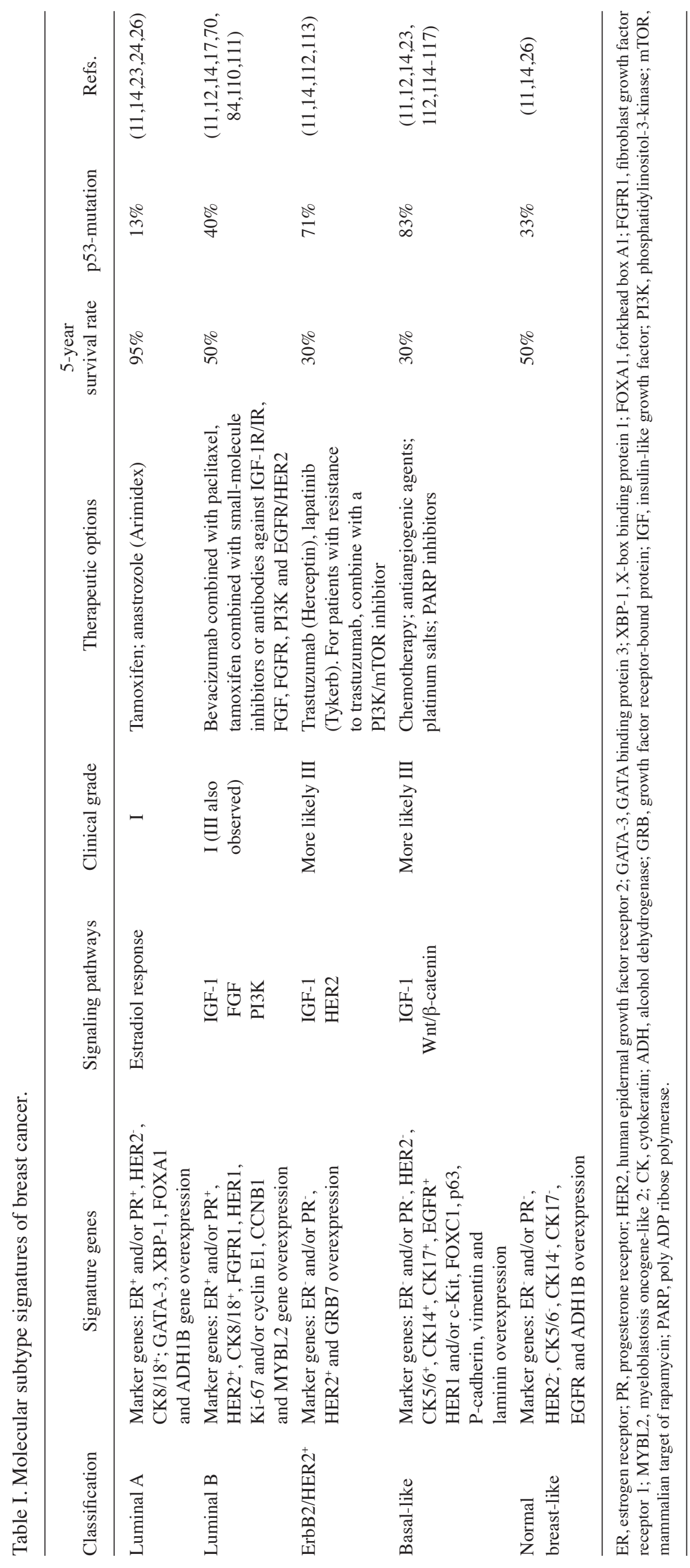




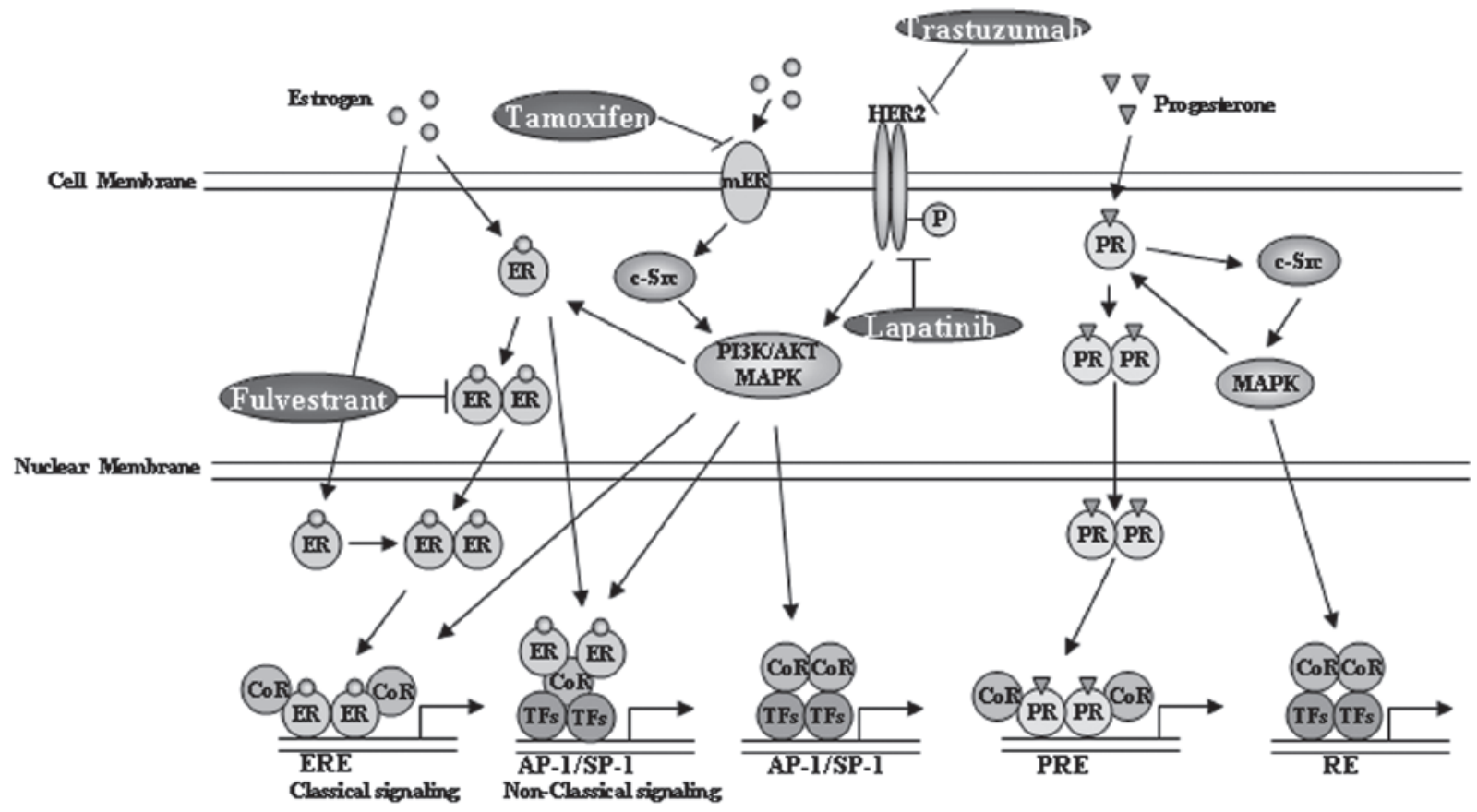

Figure 1. The estrogen receptor (ER) pathway includes the canonical and the non-canonical ER pathways. In the canonical pathway, the cytoplasmic estrogens bind directly to the nuclear membrane estrogen receptor and activate signaling. In the non-canonical pathway, the extracellular estrogens bind to the plasma membrane receptors and activate the phosphatidylinositol-3-kinase (PI3K) or Ras signaling pathway. Alternatively, the estrogens first penetrate through the cell membrane and then bind to the estrogen receptor monomer, which is then dimerized and transported into the nucleus to activate signaling. Treatment with tamoxifen blocks the binding of estrogen and, thus, inhibits the estrogen-activated signaling. Treatment with fulvestrant inhibits the cytoplasmic dimerization of estrogen. Treatment with aromatase inhibitors, such as letrozole, anastrozole and exemestane blocks estrogen production. Another characteristic correlated to the ER pathway is the progesterone receptor (PR) signaling, which is also involved in the regulation of luminal type breast cancer development. CoR, coregulators; RE, response element; TFs, transcription factors; mER, membrane ER; HER, human epidermal growth factor receptor; MAPK, mitogen-activated protein kinase; ERE, estrogen response element; PRE, progesterone response element.

(Oncotype DX) recurrence score, the MammaPrint assay score and the Rotterdam 76-gene assay score, demonstrated that low-risk tumors ( $>90 \%$ distal recurrence-free survival at 8.5 years) were identified mostly as luminal A tumors (47).

Luminal A subtype breast cancer therapeutic potentials. Estrogen is a steroid hormone that is crucial for growth, development and reproduction (48). Estrogens have been shown to play an important role in human breast cancer development and $\sim 1 / 3$ of breast cancers are stimulated by estradiol (49). Estrogens exert their effects through the action of the estrogen receptors $\alpha$ and $\beta$ (ER $\alpha$ and $E R \beta)$, which belong to the steroid hormone superfamily of nuclear receptors (NRs) $(50,51)$. ERs are members of the large NR family of transcription factors that are typically activated upon binding to small lipophilic molecules (52). The activities of steroid receptors, particularly ERs, have been associated with the regulation of breast epithelial cell cycle transition from the G0 into the $S$ phase $(53,54)$. Since $75 \%$ of breast cancers express ER $\alpha$, the significance of $\mathrm{ER} \alpha$ in breast cancer is well-established $(55,56)$.

Since luminal subtype A and B breast cancer cells are $\mathrm{ER}^{+}$and/or $\mathrm{PR}^{+}$, patients with these two types of breast cancer are always subjected to endocrine therapy with tamoxifen, to inhibit the functions of ER (57), and aromatase inhibitors or inactivators (58), to block estrogen production or to inactivate ERs, or even to inhibit the dimerization and downregulate ERs (59-61). The therapeutic strategies that may interrupt the estrogen signaling pathway have been proven effective for the $\mathrm{ER}^{+}$subtype of breast cancer (62) and are currently the first-line clinical treatment option $(63,64)$ (Fig. 1).

However, in $\mathrm{ER}^{+}$patients, the clinical therapeutic practices with endocrine therapy to antagonize ER signaling were proven to be $30 \%$ effective (65). Hormonal therapy with tamoxifen may only be beneficial for tumors exhibiting nuclear ER expression, since membrane ERs may activate EGFR and/or HER2 signaling, which may then stimulate tumor growth (66) (Fig. 2). Other signaling pathways may also be involved, such as the insulin-like growth factor 1 (IGF-1) or the vascular endothelial growth factor (VEGF) signaling pathways $(67,68)$ (Fig. 2). Thus, for $\mathrm{ER}^{+}$breast cancers, different molecular subtypes have been further described, such as the five-biomarker panel (69) signatured by ER, PR, HER2, CK 5/6 and EGFR. The primary considerations regarding treatment options are the gene signature profiles, including the Ki-67 status (17) that distinguishes luminal A from luminal B subtype; the nuclear ER signaling pathway components that distinguish luminal A from other subtypes; the HER2 signaling pathway components that distinguish the $\mathrm{ER}^{+} / \mathrm{PR}^{+}$with $\mathrm{HER} 2^{+}$from the HER2- subtype; and the EGFR, or IGF-1, VEGF and PI3K/AKT signaling pathway components. To overcome the ineffectiveness of tamoxifen treatment, luminal type breast cancers are also subjected to other therapeutic strategies, such as treatment with the anti-VEGF antibody bevacizumab combined with paclitaxel, which has also been proven effective (70). Treatment with motesanib (which is a novel, highly selective inhibitor of 


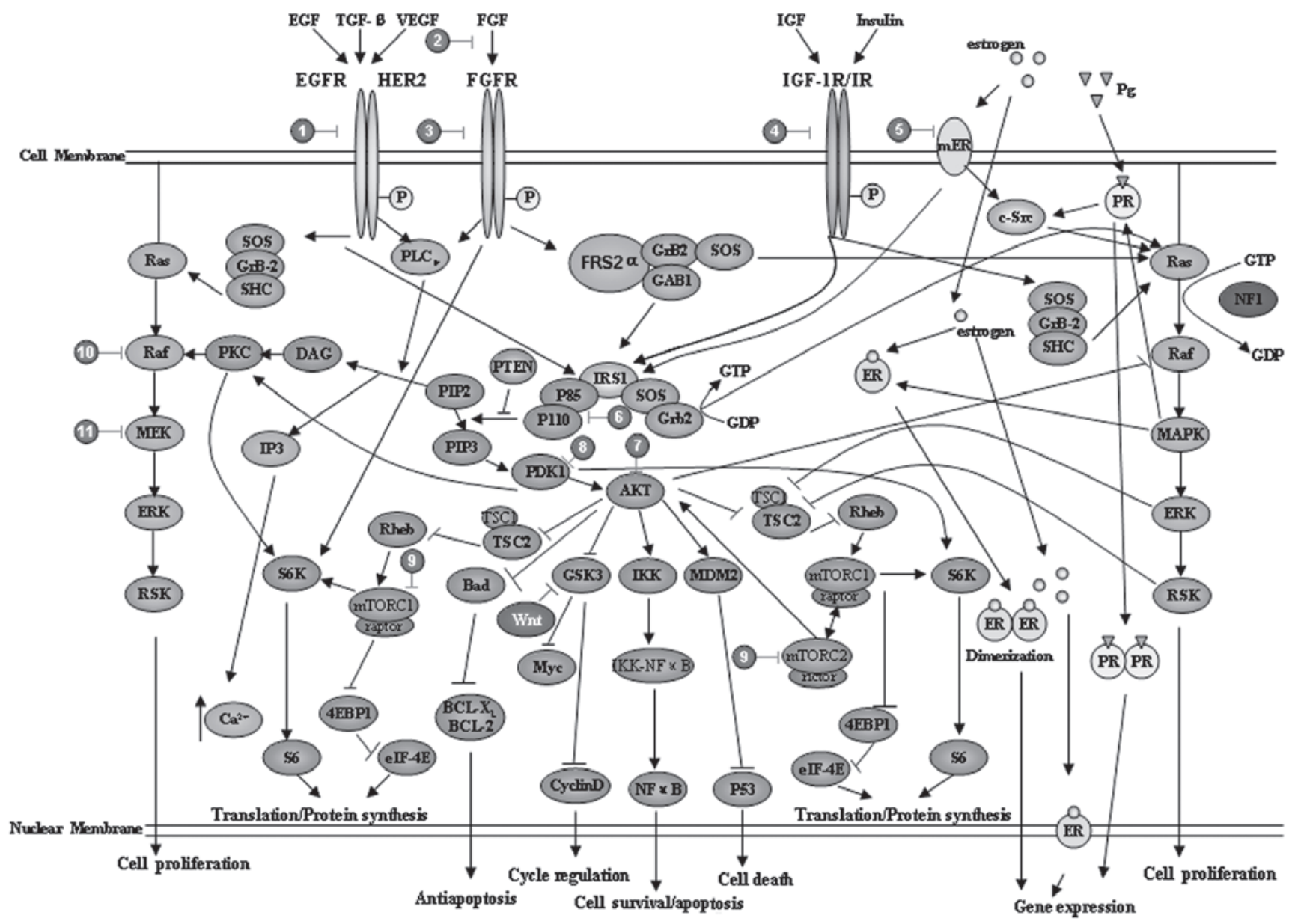

Figure 2. Crosstalk of signaling pathways in breast cancer and the potential clinical therapeutic targets. The receptors of extracellular small molecules shown here include: epidermal growth factor (EGF), transforming growth factor (TGF)- $\beta$, vascular endothelial growth factor (VEGF), fibroblast growth factor (FGF), insulin-like growth factor (IGF)-1, insulin and estrogen, which activate their corresponding receptors and further transduce the signals mainly through the phosphatidylinositol-3-kinase (PI3K)/AKT pathway or the Ras/MEK pathway. A number of PI3K/AKT and Ras/MEK signaling pathway inhibitors have been developed, some of which may be used in combination (details also summarized in Table II). Pg, progesterone; ER, estrogen receptor; PR, progesterone receptor; ERK, extracellular signal-regulated kinase; RSK, ribosomal S6 kinase; IP, inositol phosphate; PKC, protein kinase C; PTEN, phosphatase and tensin homolog; PDK, phosphoinositide-dependent kinase; mTOR, mammalian target of rapamycin; MAPK, mitogen-activated protein kinase.

VEGFR1, VEGFR2, VEGFR3, KIT and platelet-derived growth factor receptor) in combination with the ER modulator tamoxifen also resulted in a significant reduction in tumor volume (71). Of note, inhibition of the PI3K pathway signaling in endocrine treatment-resistant breast cancer cell lines was shown to reduce cell survival and improve the treatment response to endocrine agents, providing further scientific rationale to target both ERs and the PI3K pathway in order to improve the outcome of $\mathrm{ER}^{+}$breast cancer (72).

Based on the molecular signatures of luminal A subtype breast cancer, the luminal A subtype signature genes, such as GATA-3 and FOXA1, also appear to be promising therapeutic targets. Among these, the expression of FOXA1 was positively correlated with ER-positivity, particularly luminal A type ER-positivity, and negatively correlated with tumor size, tumor grade, nodal status, the expression of Ki-67 and HER2 and basal-like subtype of breast cancer (31). A previous study reported that the expression of FOXA1 was positively correlated with $\mathrm{ER}^{+}$and $\mathrm{PR}^{+}$status, but inversely correlated with nuclear grade and the Ki-67 index, suggesting the therapeutic potentials of FOXA1 targeting (73). Moreover, the forkhead box O3a (FOXO3a) transcription factor was identified as an intracellular mediator of ER $\alpha$ expression and an important downstream target of the PI3K/AKT pathway, thus representing a potential therapeutic target in $\mathrm{ER}^{+}$breast cancer (74).

An alternative way for the therapeutic considerations in luminal A subtype of breast cancer is targeting other members that are coexpressed with ER in the superfamily of steroid receptors, including estrogen-related receptors, PRs (Fig. 1), ARs, glucocorticoid and mineralocorticoid receptors. The PR A and B isoforms were demonstrated to play different roles in breast cancer cell growth and have thus been considered as therapeutic targets of antiprogestin (75). PR has been clinically used for evaluating ER activity (64) and the loss of PR in $\mathrm{ER}^{+}$ tumors is considered to be predictive of the lack of response to hormone therapy (76). However, the estrogen response element (ERE) transcriptional activity remains a better readout of ER function, as PR is just one of the numerous ER target genes and is regulated by several other transcription factors, such as Sp1 or AP-1 (77,78). High ERE-activity is correlated with the luminal A type of breast cancer and low ERE-activity is correlated with the malignancy biomarker Ki-67 (79). 


\section{Luminal B subtype breast cancer molecular signatures and therapeutic potentials}

Luminal B subtype breast cancer molecular signatures. The major molecular distinctions between luminal type A and B tumors are that luminal type A tumors exhibit a higher expression of ER-related genes and luminal type B tumors exhibit a higher expression of proliferation-related genes, such as CCNB1, MKI67 and myeloblastosis oncogene-like 2 (MYBL2) $(2,11,23,57,80)$. In contrast to the luminal A subtype, the 5-year survival rate of luminal B breast cancer is $50 \%$, with a p53 mutation rate of $40 \%$ (11), indicating the similarities between luminal B subtype and p53-mutated tumors. Badve et al (24) suggested that the better prognosis of luminal A compared to that of luminal B breast cancer may be due to the different function of ER in luminal A and B cancers and the effect of additional factors, such as coactivators, corepressors and transcription factors that modulate ER $\alpha$ activity.

In addition to sharing similar signatures with luminal subtype A, such as ER and Bcl-2, luminal subtype B tumors also share similar signatures with the basal-like subtype tumors, including the proliferation markers Ki-67, survivin and CCNB1, as well as similar signatures with the HER2 subtype, such as the overexpression of HER2 (4). The Ki-67 proliferation index was previously used as a potential unidimensional proliferation marker to distinguish luminal B from luminal A tumors (17). Thus, the Ki-67 index is the most useful signature that distinguishes high-risk luminal B from low-risk luminal A tumors (81). In addition to the differences in ER-related and proliferation-related gene expression, emerging evidence demonstrated the amplification of growth receptor signaling genes in luminal type B tumors, such as the overexpression of fibroblast growth factor receptor 1 (FGFR1) in luminal type B cancer patients (82), which may contribute to the poor prognosis of luminal B compared to luminal A cancer patients $(2,11)$, despite their clinical $\mathrm{ER}^{+}$status $(83)$. Thus, the typical signature genes in luminal subtype B tumors include FGFR1, HER1, cyclin E1 and Ki-67 $(2,11,12,17,82)$. Using the luminal A subtype as a reference, according to the multivariate analysis of untreated early-stage breast cancer, the relapse-free survival of luminal B breast cancer exhibited a hazard ratio of $2.43(\mathrm{P}<0.0001)$, similar to ErbB2/HER2 amplified tumors with a hazard ratio of $2.53(\mathrm{P}=0.00012)(23,84)$. The immunohistochemical analysis further demonstrated that $\sim 20 \%$ of luminal B cancers were HER $2^{+}$and $\sim 30 \%$ of HER2-expressing tumors were of the luminal B subtype (85). Clinically, the luminal (A and B) type breast cancers are often grade I; however, the luminal B breast cancers are often of the HER $2^{+}$genotype and are more likely to be high-grade compared to luminal A cancers $(6,11,57)$. More comprehensive gene signature profiles of the luminal type breast cancers have been provided by assays based on the platforms of the 21-gene signature assay Oncotype DX (Genomic Health, Redwood City, CA, USA) and the 70-gene signature-based MammaPrint assay (Agendia, Amsterdam, The Netherlands), as well as others $(8,86)$.

Although luminal B cancers are $\mathrm{ER}^{+}$, they do not appear to exhibit a corresponding expression of estrogen-regulated genes and may therefore depend on alternative pathways for growth. Candidate pathways that may be targeted in luminal B cancer cells include those involving growth factor receptors, such as HER2 and EGFR, as well as the PI3K/AKT/mTOR pathway. The standards for distinguishing luminal A from luminal B cancers are the Ki-67 index (cut-off value, 14\%), clinicopathological factors, such as age at diagnosis, intensity score of ER and PR, histological grade, Bcl-2 (cut-off value, $33 \%$ ) and disease-free survival (DFS).

Luminal B subtype breast cancer therapeutic potentials. Similar to luminal A, luminal B breast cancer is currently treated as an $\mathrm{ER}^{+}$, hormone-sensitive disease $(20,86)$. However, luminal B breast cancer is often considered as a more aggressive form of the luminal $\left(\mathrm{ER}^{+}\right)$type of breast cancer. The PAM50 assay results demonstrated that, although luminal subtype B breast cancers share some gene expression patterns with luminal subtype A breast cancers (e.g., ER genes ESR1, FOXA1 and Bcl-2), they also share some gene expression patterns with basal-like breast cancers (e.g., Ki-67 gene MKI67, survivin gene BIRC5 and cyclin B1 gene CCNB1) (87).

A major characteristic of luminal type B breast cancer cells is the expression of the HER2 gene $(4,88)$. The immunohistochemical results demonstrated that $30 \%$ of HER2 ${ }^{+}$ breast cancer cells are luminal type B and in this type of cell the PI3K/AKT, Ras/mitogen-activated protein kinase (MAPK) and phospholipase $\mathrm{C} \gamma(\mathrm{PLC} \gamma) /$ protein kinase $\mathrm{C}$ (PKC) signaling pathways are also involved (84) (Fig. 2 and Table II). Thus, recent clinical trials considered targeting of alternative pathways in luminal B cancer, such as using the drug gefitinib to target EGFR (89) and everolimus to target PI3K/AKT/mTOR (90). Numerous small-molecule inhibitors or antibodies targeting these signaling pathway elements have been designed and investigated, such as BMS-754807, cixutumumab, MK-0646, dalotuzumab, OSI-906 and CP-758171. Other examples include targeting the IGF-1R pathway with TKI-258 and AZD-4547 and targeting the PI3K/AKT pathway with MK-2206, XL-147 and XL-765 (84).

Another characteristic of luminal B tumors is the high expression levels of Ki-67 combined with HER2 expression, exhibiting high scores in the Oncotype DX gene expression profile. Thus, for patients with $\mathrm{HER} 2^{+}$and $\mathrm{ER}^{+}$tumors, combination treatment with endocrine and anti-HER 2 therapy may achieve therapeutic benefits (91). In addition, the Ki-67 and p53 signatured subtypes mainly belong to the luminal B subtype $(92,93)$, preconditioning for endocrine resistance (94). Moreover, previous studies demonstrated that, following neoadjuvant endocrine treatment, changes in the expression of Ki-67 may predict long-term outcome $(95,96)$. Among the prognostic factors, ER <10\%, Ki-67 >14\% and HER2 overexpression are considered as risk factors (97).

In luminal B-type tumors, the high expression levels of Ki-67 combined with HER2 expression exhibit high scores in the Oncotype DX gene expression profile; thus, for patients with $\mathrm{HER}_{2}{ }^{+}$and $\mathrm{ER}^{+}$tumors, the combination of endocrine and anti-HER2 therapy may achieve therapeutic benefits (91). However, in $\mathrm{ER}^{+} / \mathrm{PR}^{-}$luminal breast tumors, aggressive behavior and tamoxifen resistance are characteristic, despite the $\mathrm{ER}^{+}$status (98). This subtype of luminal type breast cancers was classified as luminal B tumors, with greater genomic instability and a higher proliferation rate, as well as elevated growth factor signaling and membranous ER 
Table II. Inhibitors or antibodies for signaling pathway elements in breast cancer.

\begin{tabular}{|c|c|c|c|}
\hline No. & Target & Target agents & Refs. \\
\hline \multirow[t]{5}{*}{1} & HER2 & $\begin{array}{l}\text { Trastuzumab (Herceptin); pertuzumab (Omnitarg); } \\
\text { CP-724,714; TAK165; CI-1033; 2C4; AG1478; ARRY-380 }\end{array}$ & $(113,118-120)$ \\
\hline & EGFR/HER2 & $\begin{array}{l}\text { Lapatinib (Tykerb); AEE-788; BMS-599626; ARRY-334543; } \\
\text { BIBW2992; HKI-272; MP-412; CI-1033 (canertinib); } \\
\text { neratinib (HKI-272); CUDC-101; AZD8931; BMS-599626; } \\
\text { ARRY-334543; dacomitinib (PF-00299804); TAK-285 }\end{array}$ & $(113,121-128)$ \\
\hline & EGFR & $\begin{array}{l}\text { Gefitinib (ZD-1839, Iressa); CPI-358,774; cetuximab; } \\
\text { OSI-774; PD153035; erlotinib }\end{array}$ & $(118,129,130)$ \\
\hline & VEGFRs & $\begin{array}{l}\text { Regorafenib (BAY 73-4506) }{ }^{\text {a }} \text { BAY 43-9006; OSI-930; } \\
\text { SU11248 } \text {; axitinib (AG-013736); cediranib (AZD2171); } \\
\text { vandetanib (Zactima, ZD6474); motesanib diphosphate (AMG-706); } \\
\text { E7080 (lenvatinib); ENMD-2076; telatinib (BAY 57-9352); } \\
\text { linifanib (ABT-869); apatinib (YN968D1); } \\
\text { cabozantinib (XL184); RAF265 (CHIR-265) }\end{array}$ & $(71,131-144)$ \\
\hline & EGFR/VEGFRs & AEE-788; EXEL-7647 (XL647) & $(113,145)$ \\
\hline 2 & FGF & 1A6; FP-1039; palifermin (Kepivance) & $(146)$ \\
\hline 3 & FGFRs & $\begin{array}{l}\text { SU5402; PD173074; TKI-258; BIBF 1120; } \\
\text { BMS-582,664 (brivanib); E7080; TSU-68; IMC-A1; } \\
\text { PRO-001; R3Mab; AZD-4547; ENMD-2076; AZD4547 }\end{array}$ & $(84,139,146,147)$ \\
\hline 4 & $\begin{array}{l}\text { IGF-1R } \\
\text { IGF-1R/IR }\end{array}$ & $\begin{array}{l}\text { BMS-754807; NVP-AEW541 } \\
\text { Cixutumumab; MK-0646; dalotuzumab; CP-758171; } \\
\text { BMS-554417; BMS-536924; GSK1904529A; } \\
\text { OSI-906 (linsitinib); AG-1024 (Tyrphostin); GSK1838705A }\end{array}$ & $\begin{array}{c}(84,148) \\
(84,125,149-152)\end{array}$ \\
\hline 5 & ER & $\begin{array}{l}\text { ICI 182,780; tamoxifen; Casodex; fulvestrant; letrozole; } \\
\text { anastrozole; exemestane }\end{array}$ & $(60,153,154)$ \\
\hline \multirow[t]{2}{*}{6} & PI3K & $\begin{array}{l}\text { Wortmannin; BKM120; LY294002; XL-147; GDC-0941; } \\
\text { PX-866; ZSTK474; SF1126; IC486068; fused heteroaryl and } \\
\text { imidazopyridine-based inhibitors; WAY-266176; } \\
\text { WAY-266175; PIK75 }\end{array}$ & $\begin{array}{l}(60,84,111,129,153 \\
155-157)\end{array}$ \\
\hline & $\mathrm{PI} 3 \mathrm{~K} / \mathrm{mTOR}$ & $\begin{array}{l}\text { BEZ235; XL-765; GSK2126458; PKI-402; GDC-0980; } \\
\text { PF-05212384 (PKI-587) }\end{array}$ & $(60,84,158-161)$ \\
\hline 7 & AKT & $\begin{array}{l}\text { MK-2206; PX-316; perifosine (KYX-0401); UCN-01; } \\
\text { GSK690693; AT7867; PHT-427; triciribine }\end{array}$ & $(84,129,162-165)$ \\
\hline 8 & PDK1 & OSU-03012; PHT-427; BX-795; BX-912; BX-320; & $(129,164,166)$ \\
\hline \multirow[t]{2}{*}{9} & mTORC1 & $\begin{array}{l}\text { Everolimus; rapamycin; RAD-001; temsirolimus (CCI-779); } \\
\text { ridaforolimus (AP23573; MK-8669); PF-04691502; }\end{array}$ & $(60,167-170)$ \\
\hline & mTORC1/2 & $\begin{array}{l}\text { OXA-01; OSI-027; AZD8055; WYE-125132 (WYE-132); } \\
\text { GSK2126458; GDC-0980; WAY-600; WYE-687; WYE-354; } \\
\text { AZD2104; IKK-128; XL388 }\end{array}$ & $(133,158,171-176)$ \\
\hline 10 & Raf & $\begin{array}{l}\text { Regorafenib (BAY 73-4506) }{ }^{\text {b; }} \text { sorafenib (BAY 43-9006, Nexavar); } \\
\text { RAF265 }\end{array}$ & $(131,132,144)$ \\
\hline 11 & MEK1/2(MAPK) & UO126; PD98059; CI-1040 (PD184352); UCN-01; PD318088 & $(119,153,156,177,178)$ \\
\hline
\end{tabular}

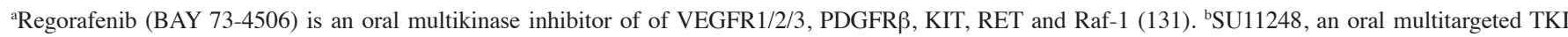
with antiangiogenic and antitumor activity, inhibits VEGF, PDGF, KIT and FLT3 receptor TKs (70). ${ }^{\mathrm{C} A p a t i n i b}$ (YN968D1) is a small-molecule TKI that inhibits VEGFR2 (Flk-1/KDR), RET (rearranged during transfection), c-Kit (stem cell factor receptor) and c-Src tyrosine kinases (142). HER, human epidermal growth factor receptor; ER, estrogen receptor; EGFR, epidermal growth factor receptor; VEGFR, vascular endothelial growth factor receptor; FGF, fibroblast growth factor receptor; IGF, insulin-like growth factor; PI3K, phosphatidylinositol-3-kinase; mTOR, mammalian target of rapamycin; PDK, phosphoinositide-dependent kinase; MAPK, mitogen-activated protein kinase; PDGFR, platelet-derived growth factor receptor; FLT, FMS-like tyrosine kinase; TKI, tyrosine kinase inhibitor.

activity (98). Luminal subtype B cancer patients also exhibit a higher expression of HER 1 and HER 2 and active gowth factor signaling mediated by the PI3K/AKT/mTOR pathway (98) (Fig. 2 and Table II). Thus, the optimal treatment approach for this subset of patients may be the combination of aromatase inhibitors, fulvestrant and chemotherapy. It was also demonstrated that $\mathrm{PR}^{-}$luminal B tumors that were treated with neoadjuvant chemotherapy (adriamycin/cyclophosphamide) 
exhibited a significantly improved response compared to other types of tumors (99).

Higher PI3K signature scores have been observed in $\mathrm{ER}^{+}$ tumors and the cell lines of the more aggressive luminal $\mathrm{B}$ compared to those of the less aggressive luminal A molecular subtype, suggesting that targeting PI3K in these tumors may reverse the loss of ER expression and signaling and restore hormonal sensitivity (100). Inhibition of PI3K pathway signaling in endocrine-resistant luminal B subtype breast cancer cells reduces cell survival and improves treatment response to endocrine agents (72), providing further potential therapeutic strategies by targeting both the ER and the PI3K pathway, in order to improve the outcome of $\mathrm{ER}^{+}$breast cancer. In the $\mathrm{ER}^{+} / \mathrm{PR}^{-}$luminal $\mathrm{B}$ subtype breast cancer cells, the binding of estrogen or tamoxifen to the ER on the plasma membrane activates EGFR and HER2 and their downstream signaling pathways, including MAPK and PI3K/AKT/mTOR pathway, leading to tamoxifen resistance $(76,101,102)$. The corresponding strategies for this type of breast cancer are aromatase inhibitors, fulvestrant and chemotherapy, plus targeted therapies, such as gefitinib, to overcome tamoxifen resistance (103).

Charafe-Jauffret et al (104) demonstrated that ErbB2 is mainly overexpressed in luminal breast cancer cell lines, rather than in basal-like breast cancer cell lines. Additional characteristics of the luminal type B breast cancer cells include the expression of CCNB1, MKI67, MYBL2, FGFR1 and ZNF703 genes that are associated with resistance to tamoxifen and poor treatment outcome $(25,105,106)$. Thus, the treatment effectiveness of tamoxifen for luminal subtype B is lower compared to that for luminal type A breast cancers. Other luminal subtype B breast cancer signature genes, such as ZNF703, identified in luminal subtype B breast cancer, were shown to modulate luminal B cancer stem cells (106). The NHERF1 gene, expressed in luminal B subtype breast cancer, was associated with a worse survival in $\mathrm{ER}^{+}$breast cancer and the low NHERF1 expression genotype may benefit from endocrine therapy (107). The P-Rex1 gene, a Rac-specific guanine nucleotide exchanging factor, is highly overexpressed in ErbB2 ${ }^{+}$and $\mathrm{ER}^{+}$double-positive luminal type breast cancers, thus suggesting the possibility of targeting the P-Rex1/Rac signaling pathway for luminal subtype B breast cancer therapy (98). Bergamaschi et al (108) demonstrated that the elevated 14-3-3 $\zeta$ expression promoted resistance to endocrine therapy with tamoxifen in luminal $\mathrm{B}$ cancer patients and corresponding to the elevated 14-3-3 $\zeta$ expression were genes such as aurora kinase B, polo-like kinase 1, CDC25B, BIRC5/survivin and FOXM1, providing a wider target selection base for luminal B subtype breast cancers. In a previous study of a 96-patient cohort, Glynn et al (109) reported that retinoic acid receptor $\alpha$ levels were significantly higher in HER2/neu ${ }^{+}$and $\mathrm{ER}^{+}$patients compared to HER2/neu ${ }^{+}$and $\mathrm{ER}^{-}$patients, adding another gene expression signature to the therapeutic options for $\mathrm{HER} 2 / \mathrm{neu}^{+}$and $\mathrm{ER}^{+}$luminal subtype B breast cancer.

\section{Challenges and perspectives}

The present molecular classifications assigned $\mathrm{ER}^{+}$breast cancer into two categories: the luminal subtype A, characterized by $\mathrm{ER}^{+} / \mathrm{PR}^{+} / \mathrm{HER} 2 /$ low $\mathrm{Ki}-67$; and the luminal subtype B, characterized by $\mathrm{ER}^{+} / \mathrm{PR}^{+} / \mathrm{HER}^{+}$or $\mathrm{ER}^{+} / \mathrm{PR}^{+} /$high $\mathrm{Ki}-67$. Based on these molecular signatures, effective diagnostic and therapeutic decisions are enabled, with subsequent improved clinical outcomes. However, these simplified signatures are unable to accurately represent the complex intrinsic processes of tumor cell growth. The details of the molecular processes within the tumor cell have not been elucidated, nor have the mechanisms of treatment resistance, the clear panorama of the molecular networks and the molecular cascade upon treatment. In addition, the treatment interventions in the tumor suppressor genes have not been adequately investigated and the effect of the microenvironment on treatment efficacy has not been determined. The applications of several molecular signature sets, including the Oncotype DX and MammaPrint assays mentioned earlier, have been demonstrated to be powerful tools enabling more accurate predictions and effective therapeutic decisions. The prediction values of these assays have also been confirmed when combined with other approaches. However, due to the heterogeneous properties of the breast cancer subtypes and the complex molecular processes underlying breast cancer development, these molecular signature sets are not considered sufficient for practical clinical application. In addition, accumulating data have demonstrated the individual differences based on genomic sequencing results of clinical samples. Although the individual genomic differences may not reflect the decisive molecular mechanisms, they are a reminder of the heterogeneity and complexity of the decision-making process. The combination of the present molecular signature sets with accumulating data obtained by the new-generation sequencing technology and the high throughput gene expression quantification technology may enable obtaining more reliable molecular signature sets for future diagnosis and prediction of human breast cancer.

\section{Acknowledgements}

This study was funded by the 'Financial support for selected researchers back from abroad (2011)’ of Liaoning Province.

\section{References}

1. Pedraza V, Gomez-Capilla JA, Escaramis G, et al: Gene expression signatures in breast cancer distinguish phenotype characteristics, histologic subtypes, and tumor invasiveness. Cancer 116: 486-496, 2010.

2. Sorlie T, Tibshirani R, Parker J, et al: Repeated observation of breast tumor subtypes in independent gene expression data sets. Proc Natl Acad Sci USA 100: 8418-8423, 2003.

3. Bánkfalv A, Ludwig A, De-Hesselle B, Buerger H, Buchwalow IB and Boecker W: Different proliferative activity of the glandular and myoepithelial lineages in benign proliferative and early malignant breast diseases. Mod Pathol 17: 1051-1061, 2004.

4. Prat A and Perou CM: Deconstructing the molecular portraits of breast cancer. Mol Oncol 5: 5-23, 2011.

5. van't Veer LJ, Dai H, van de Vijver MJ, et al: Gene expression profiling predicts clinical outcome of breast cancer. Nature 415: 530-536, 2002.

6. Sotiriou C, Neo SY, McShane LM, et al: Breast cancer classification and prognosis based on gene expression profiles from a population-based study. Proc Natl Acad Sci USA 100: 10393-10398, 2003.

7. Chung CH, Bernard PS and Perou CM: Molecular portraits and the family tree of cancer. Nat Genet 32: 533-540, 2002.

8. Paik S, Shak S, Tang G, et al: A multigene assay to predict recurrence of tamoxifen-treated, node-negative breast cancer. N Engl J Med 351: 2817-2826, 2004. 
9. Peinado H, Olmeda D and Cano A: Snail, Zeb and bHLH factors in tumour progression: an alliance against the epithelial phenotype? Nat Rev Cancer 7: 415-428, 2007.

10. Liu N, Yu Q, Liu TJ, et al: P-cadherin expression and basal-like subtype in breast cancers. Med Oncol 29: 2606-2612, 2012.

11. Sørlie T, Perou CM, Tibshirani R, et al: Gene expression patterns of breast carcinomas distinguish tumor subclasses with clinical implications. Proc Natl Acad Sci USA 98: 10869-10874, 2001.

12. Carey LA, Perou CM, Livasy CA, et al: Race, breast cancer subtypes, and survival in the Carolina Breast Cancer Study. JAMA 295: 2492-2502, 2006.

13. Onitilo AA, Engel JM, Greenlee RT and Mukesh BN: Breast cancer subtypes based on ER/PR and Her2 expression: comparison of clinicopathologic features and survival. Clin Med Res 7: 4-13, 2009.

14. Perou CM, Sørlie T, Eisen MB, et al: Molecular portraits of human breast tumours. Nature 406: 747-752, 2000.

15. Herschkowitz JI, Simin K, Weigman VJ, et al: Identification of conserved gene expression features between murine mammary carcinoma models and human breast tumors. Genome Biol 8 R76, 2007.

16. Creighton CJ, Li X, Landis M, et al: Residual breast cancers after conventional therapy display mesenchymal as well as tumor-initiating features. Proc Natl Acad Sci USA 106: 13820-13825, 2009.

17. Cheang MC, Chia SK, Voduc D, et al: Ki67 index, HER2 status, and prognosis of patients with luminal B breast cancer. J Natl Cancer Inst 101: 736-750, 2009.

18. Fountzilas G, Dafni U, Bobos M, et al: Differential response of immunohistochemically defined breast cancer subtypes to anthracycline-based adjuvant chemotherapy with or without paclitaxel. PLoS One 7: e37946, 2012.

19. Hannemann J, Kristel P, van Tinteren H, et al: Molecular subtypes of breast cancer and amplification of topoisomerase I alpha: predictive role in dose intensive adjuvant chemotherapy. Br J Cancer 95: 1334-1341, 2006.

20. Goldhirsch A, Wood WC, Coates AS, Gelber RD, Thurlimann B and Senn HJ: Strategies for subtypes - dealing with the diversity of breast cancer: highlights of the St. Gallen International Expert Consensus on the Primary Therapy of Early Breast Cancer 2011 Ann Oncol 22: 1736-1747, 2011.

21. Hoch RV, Thompson DA, Baker RJ and Weigel RJ: GATA-3 is expressed in association with estrogen receptor in breast cancer. Int J Cancer 84: 122-128, 1999.

22. Jordan VC, Wolf MF, Mirecki DM, Whitford DA and Welshons WV: Hormone receptor assays: clinical usefulness in the management of carcinoma of the breast. Crit Rev Clin Lab Sci 26: 97-152, 1988 .

23. Hu Z, Fan C, Oh DS, et al: The molecular portraits of breast tumors are conserved across microarray platforms. BMC Genomics 7: 96, 2006

24. Badve S, Turbin D, Thorat MA, et al: FOXA1 expression in breast cancer - correlation with luminal subtype A and survival. Clin Cancer Res 13: 4415-4421, 2007.

25. Oh DS, Troester MA, Usary J, et al: Estrogen-regulated genes predict survival in hormone receptor-positive breast cancers J Clin Oncol 24: 1656-1664, 2006.

26. Smid M, Wang Y, Zhang Y, et al: Subtypes of breast cancer show preferential site of relapse. Cancer Res 68: 3108-3114, 2008

27. van de Vijver MJ, He YD, van't Veer LJ, et al: A gene-expression signature as a predictor of survival in breast cancer. N Engl J Med 347: 1999-2009, 2002

28. Lacroix M and Leclercq G: About GATA3, HNF3A, and XBP1, three genes co-expressed with the oestrogen receptor-alpha gene (ESR1) in breast cancer. Mol Cell Endocrinol 219: 1-7, 2004.

29. Carroll JS and Brown M: Estrogen receptor target gene: an evolving concept. Mol Endocrinol 20: 1707-1714, 2006.

30. Carroll JS, Liu XS, Brodsky AS, et al: Chromosome-wide mapping of estrogen receptor binding reveals long-range regulation requiring the forkhead protein FoxA1. Cell 122: 33-43, 2005.

31. Mehta RJ, Jain RK, Leung S, et al: FOXA1 is an independent prognostic marker for ER-positive breast cancer. Breast Cancer Res Treat 131: 881-890, 2012.

32. Hurtado A, Holmes KA, Ross-Innes CS, Schmidt D and Carroll JS: FOXA1 is a key determinant of estrogen receptor function and endocrine response. Nat Genet 43: 27-33, 2011.

33. Fang SH, Chen Y and Weigel RJ: GATA-3 as a marker of hormone response in breast cancer. J Surg Res 157: 290-295, 2009.
34. Chou J, Provot S and Werb Z: GATA3 in development and cancer differentiation: cells GATA have it! J Cell Physiol 222: 42-49, 2010.

35. Mehra R, Varambally S, Ding L, et al: Identification of GATA3 as a breast cancer prognostic marker by global gene expression meta-analysis. Cancer Res 65: 11259-11264, 2005.

36. Dolled-Filhart M, Rydén L, Cregger M, et al: Classification of breast cancer using genetic algorithms and tissue microarrays. Clin Cancer Res 12: 6459-6468, 2006.

37. Asselin-Labat ML, Sutherland KD, Barker H, et al: Gata-3 is an essential regulator of mammary-gland morphogenesis and luminal-cell differentiation. Nat Cell Biol 9: 201-209, 2007.

38. Dawson SJ, Makretsov N, Blows FM, et al: BCL2 in breast cancer: a favourable prognostic marker across molecular subtypes and independent of adjuvant therapy received. $\mathrm{Br} \mathrm{J}$ Cancer 103: 668-675, 2010.

39. Ali HR, Dawson SJ, Blows FM, et al: A Ki67/BCL2 index based on immunohistochemistry is highly prognostic in ER-positive breast cancer. J Pathol 226: 97-107, 2012.

40. Abdel-Fatah TM, Powe DG, Ball G, et al: Proposal for a modified grading system based on mitotic index and $\mathrm{Bcl} 2$ provides objective determination of clinical outcome for patients with breast cancer. J Pathol 222: 388-399, 2010.

41. Callagy GM, Webber MJ, Pharoah PD and Caldas C: Meta-analysis confirms BCL2 is an independent prognostic marker in breast cancer. BMC Cancer 8: 153, 2008.

42. Kallel-Bayoudh I, Hassen HB, Khabir A, et al: Bcl-2 expression and triple negative profile in breast carcinoma. Med Oncol 28: S55-S61, 2010

43. Saghatchian M, Mook S, Pruneri G, et al: Additional prognostic value of the 70 -gene signature (MammaPrint ${ }^{\circledR}$ ) among breast cancer patients with 4-9 positive lymph nodes. Breast: Jan 21 , 2013 (Epub ahead of print).

44. Yokoyama J, Kobayashi T, Nakamura T and Nakajima Y: A case of male breast cancer in which oncotype DX was used to determine the therapeutic strategy. Gan To Kagaku Ryoho 39: 2057-2059, 2012 (In Japanese).

45. Morris SR and Carey LA: Molecular profiling in breast cancer. Rev Endocr Metab Disord 8: 185-198, 2007.

46. Endo Y, Toyama T, Takahashi S, et al: miR-1290 and its potential targets are associated with characteristics of estrogen receptor $\alpha$-positive breast cancer. Endocr Relat Cancer 20: 91-102, 2013

47. Prat A, Parker JS, Fan C, et al: Concordance among gene expression-based predictors for ER-positive breast cancer treated with adjuvant tamoxifen. Ann Oncol 23: 2866-2873, 2012.

48. Swedenborg E, Power KA, Cai W, Pongratz I and Rüegg J: Regulation of estrogen receptor beta activity and implications in health and disease. Cell Mol Life Sci 66: 3873-3894, 2009.

49. El-Tanani MK and Green CD: Interaction between estradiol and growth factors in the regulation of specific gene expression in MCF-7 human breast cancer cells. J Steroid Biochem Mol Biol 60: 269-276, 1997.

50. Osz J, Brelivet Y, Peluso-Iltis C, et al: Structural basis for a molecular allosteric control mechanism of cofactor binding to nuclear receptors. Proc Natl Acad Sci USA 109: E588-E594, 2012.

51. Choi KC and Jeung EB: The biomarker and endocrine disruptors in mammals. J Reprod Dev 49: 337-345, 2003.

52. Chawla A, Repa JJ, Evans RM and Mangelsdorf DJ: Nuclear receptors and lipid physiology: opening the X-files. Science 294: 1866-1870, 2001

53. Loi S, Sotiriou C, Haibe-Kains B, et al: Gene expression profiling identifies activated growth factor signaling in poor prognosis (luminal-B) estrogen receptor positive breast cancer. BMC Med Genomics 2: 37, 2009.

54. Lee HR, Hwang KA, Park MA, Yi BR, Jeung EB and Choi KC: Treatment with bisphenol A and methoxychlor results in the growth of human breast cancer cells and alteration of the expression of cell cycle-related genes, cyclin D1 and p21, via an estrogen receptor-dependent signaling pathway. Int J Mol Med 29: 883-890, 2012

55. Anderson E: The role of oestrogen and progesterone receptors in human mammary development and tumorigenesis. Breast Cancer Res 4: 197-201, 2002.

56. Hartman J, Strom A and Gustafsson JA: Estrogen receptor beta in breast cancer - diagnostic and therapeutic implications. Steroids 74: 635-641, 2009.

57. Brenton JD, Carey LA, Ahmed AA and Caldas C: Molecular classification and molecular forecasting of breast cancer: ready for clinical application? J Clin Oncol 23: 7350-7360, 2005. 
58. Mauri D, Pavlidis N, Polyzos NP and Ioannidis JP: Survival with aromatase inhibitors and inactivators versus standard hormonal therapy in advanced breast cancer: meta-analysis. J Natl Cancer Inst 98: 1285-1291, 2006.

59. Howell A, Cuzick J, Baum M, et al: Results of the ATAC (Arimidex, Tamoxifen, Alone or in Combination) trial after completion of 5 years' adjuvant treatment for breast cancer. Lancet 365: 60-62, 2005.

60. Fox EM, Arteaga CL and Miller TW: Abrogating endocrine resistance by targeting ER $\alpha$ and PI3K in breast cancer. Front Oncol 2: 145, 2012.

61. Musgrove EA and Sutherland RL: Biological determinants of endocrine resistance in breast cancer. Nat Rev Cancer 9: 631-643, 2009.

62. No authors listed: Tamoxifen for early breast cancer: an overview of the randomised trials. Early Breast Cancer Trialists Collaborative Group. Lancet 351: 1451-1467, 1998.

63. Harris TJ and McCormick F: The molecular pathology of cancer. Nat Rev Clin Oncol 7: 251-265, 2010

64. Hammond ME, Hayes DF, Dowsett M, et al: American Society of Clinical Oncology/College Of American Pathologists guideline recommendations for immunohistochemical testing of estrogen and progesterone receptors in breast cancer. J Clin Oncol 28 2784-2795, 2010.

65. Pujol P, Daures JP, Thezenas S, Guilleux F, Rouanet P and Grenier J: Changing estrogen and progesterone receptor patterns in breast carcinoma during the menstrual cycle and menopause. Cancer 83: 698-705, 1998.

66. Shou J, Massarweh S, Osborne CK, et al: Mechanisms of tamoxifen resistance: increased estrogen receptor-HER2/neu cross-talk in ER/HER2-positive breast cancer. J Natl Cancer Inst 96: 926-935, 2004.

67. Rutanen EM, Pekonen F, Nyman T and Wahlström T: Insulin-like growth factors and their binding proteins in benign and malignant uterine diseases. Growth Regul 3: 74-77, 1993.

68. O'Toole SA, Dunn E, Sheppard BL, et al: Oestrogen regulated gene expression in normal and malignant endometrial tissue. Maturitas 51: 187-198, 2005.

69. Millar EK, Graham PH, O'Toole SA, et al: Prediction of local recurrence, distant metastases, and death after breast-conserving therapy in early-stage invasive breast cancer using a five-biomarker panel. J Clin Oncol 27: 4701-4708, 2009.

70. Miller KD, Burstein HJ, Elias AD, et al: Phase II study of SU11248, a multitargeted receptor tyrosine kinase inhibitor (TKI), in patients (pts) with previously treated metastatic breast cancer (MBC). J Clin Oncol 23: 563, 2005.

71. Coxon A, Bush T, Saffran D, et al: Broad antitumor activity in breast cancer xenografts by motesanib, a highly selective, oral inhibitor of vascular endothelial growth factor, platelet-derived growth factor, and Kit receptors. Clin Cancer Res 15: 110-118, 2009.

72. Ma CX, Crowder RJ and Ellis MJ: Importance of PI3-kinase pathway in response/resistance to aromatase inhibitors. Steroids 76: 750-752, 2011

73. Hisamatsu Y, Tokunaga E, Yamashita N, et al: Impact of FOXA1 expression on the prognosis of patients with hormone receptor-positive breast cancer. Ann Surg Oncol 19: 1145-1152, 2012 .

74. Habashy HO, Rakha EA, Aleskandarany M, et al: FOXO3a nuclear localisation is associated with good prognosis in luminal-like breast cancer. Breast Cancer Res Treat 129: 11-21, 2011.

75. Lanari C, Wargon V, Rojas P and Molinolo AA: Antiprogestins in breast cancer treatment: are we ready? Endocr Relat Cancer 19: R35-R50, 2012.

76. Cui X, Schiff R, Arpino G, Osborne CK and Lee AV: Biology of progesterone receptor loss in breast cancer and its implications for endocrine therapy. J Clin Oncol 23: 7721-7735, 2005.

77. Safe S and Kim K: Nuclear receptor-mediated transactivation through interaction with Sp proteins. Prog Nucleic Acid Res Mol Biol 77: 1-36, 2004

78. Hewitt SC and Korach KS: Estrogen receptors: structure, mechanisms and function. Rev Endocr Metab Disord 3: 193-200, 2002.

79. Gohno T, Seino Y, Hanamura T, et al: Individual transcriptional activity of estrogen receptors in primary breast cancer and its clinical significance. Cancer Med 1: 328-337, 2012.

80. Perou CM, Jeffrey SS, van de Rijn M, et al: Distinctive gene expression patterns in human mammary epithelial cells and breast cancers. Proc Natl Acad Sci USA 96: 9212-9217, 1999.
81. Loi S, Haibe-Kains B, Desmedt C, et al: Definition of clinically distinct molecular subtypes in estrogen receptor-positive breast carcinomas through genomic grade. J Clin Oncol 25: 1239-1246, 2007.

82. Turner N, Pearson A, Sharpe R, et al: FGFR1 amplification drives endocrine therapy resistance and is a therapeutic target in breast cancer. Cancer Res 70: 2085-2094, 2010.

83. de Azambuja E, Cardoso F, de Castro GJ Jr, et al: Ki-67 as prognostic marker in early breast cancer: a meta-analysis of published studies involving 12,155 patients. Br J Cancer 96: 1504-1513, 2007.

84. Tran B and Bedard PL: Luminal-B breast cancer and novel therapeutic targets. Breast Cancer Res 13: 221, 2011.

85. Wirapati P, Sotiriou C, Kunkel S, et al: Meta-analysis of gene expression profiles in breast cancer: toward a unified understanding of breast cancer subtyping and prognosis signatures. Breast Cancer Res 10: R65, 2008.

86. Prat A, Ellis MJ and Perou CM: Practical implications of gene-expression-based assays for breast oncologists. Nat Rev Clin Oncol 9: 48-57, 2011.

87. Nielsen TO, Parker JS, Leung S, et al: A comparison of PAM50 intrinsic subtyping with immunohistochemistry and clinical prognostic factors in tamoxifen-treated estrogen receptor-positive breast cancer. Clin Cancer Res 16: 5222-5232, 2010.

88. Rakha EA, El-Sayed ME, Reis-Filho JS and Ellis IO: Expression profiling technology: its contribution to our understanding of breast cancer. Histopathology 52: 67-81, 2008.

89. Osborne CK, Neven P, Dirix LY, et al: Gefitinib or placebo in combination with tamoxifen in patients with hormone receptor-positive metastatic breast cancer: a randomized phase II study. Clin Cancer Res 17: 1147-1159, 2011.

90. Baselga J, Campone M, Piccart M, et al: Everolimus in postmenopausal hormone-receptor-positive advanced breast cancer. N Engl J Med 366: 520-529, 2012.

91. Lønning PE: Poor-prognosis estrogen receptor- positive disease: present and future clinical solutions. Ther Adv Med Oncol 4: 127-137, 2012.

92. Millar EK, Graham PH, McNeil CM, et al: Prediction of outcome of early $\mathrm{ER}^{+}$breast cancer is improved using a biomarker panel, which includes Ki-67 and p53. Br J Cancer 105: 272-280, 2011.

93. Jacquemier J, Charafe-Jauffret E, Monville F, et al: Association of GATA3, P53, Ki67 status and vascular peritumoral invasion are strongly prognostic in luminal breast cancer. Breast Cancer Res 11: R23, 2009.

94. Yamashita H, Toyama T, Nishio M, et al: p53 protein accumulation predicts resistance to endocrine therapy and decreased post-relapse survival in metastatic breast cancer. Breast Cancer Res 8: R48, 2006.

95. Ellis MJ, Coop A, Singh B, et al: Letrozole inhibits tumor proliferation more effectively than tamoxifen independent of HER $1 / 2$ expression status. Cancer Res 63: 6523-6531, 2003.

96. Dowsett M, Smith IE, Ebbs SR, et al: Prognostic value of Ki67 expression after short-term presurgical endocrine therapy for primary breast cancer. J Natl Cancer Inst 99: 167-170, 2007.

97. Cortesi L, De Matteis E, Cirilli C, Marcheselli L, Proietto M and Federico $\mathrm{M}$ : Outcome evaluation in pre-trastuzumab era between different breast cancer phenotypes: a population-based study on Italian women. Tumori 98: 743-750, 2012.

98. Wertheimer E, Gutierrez-Uzquiza A, Rosemblit C, LopezHaber C, Sosa MS and Kazanietz MG: Rac signaling in breast cancer: a tale of GEFs and GAPs. Cell Signal 24: 353-362, 2012.

99. Lips EH, Mulder L, Ronde JJ, et al: Neoadjuvant chemotherapy in $\mathrm{ER}^{+}$HER2- breast cancer: response prediction based on immunohistochemical and molecular characteristics. Breast Cancer Res Treat 131: 827-836, 2012.

100. Creighton CJ, Fu X, Hennessy BT, et al: Proteomic and transcriptomic profiling reveals a link between the PI3K pathway and lower estrogen-receptor (ER) levels and activity in $\mathrm{ER}^{+}$ breast cancer. Breast Cancer Res 12: R40, 2010

101. Osborne CK, Shou J, Massarweh S and Schiff R: Crosstalk between estrogen receptor and growth factor receptor pathways as a cause for endocrine therapy resistance in breast cancer. Clin Cancer Res 11: 865s-870s, 2005

102.Zhang Y, Su H, Rahimi M, Tochihara R and Tang C: EGFRvIII-induced estrogen-independence, tamoxifen-resistance phenotype correlates with $\mathrm{PgR}$ expression and modulation of apoptotic molecules in breast cancer. Int $\mathrm{J}$ Cancer 125: 2021-2028,2009. 
103. Thakkar JP and Mehta DG: A review of an unfavorable subset of breast cancer: estrogen receptor positive progesterone receptor negative. Oncologist 16: 276-285, 2011.

104. Charafe-Jauffret E, Ginestier C, Monville F, et al: Gene expression profiling of breast cell lines identifies potential new basal markers. Oncogene 25: 2273-2284, 2006.

105. Katoh M: Genetic alterations of FGF receptors: an emerging field in clinical cancer diagnostics and therapeutics. Expert Rev Anticancer Ther 10: 1375-1379, 2010.

106. Sircoulomb F, Nicolas N, Ferrari A, et al: ZNF703 gene amplification at 8p12 specifies luminal B breast cancer. EMBO Mol Med 3: 153-166, 2011.

107.Karn T, Ruckhäberle E, Hanker L, et al: Gene expression profiling of luminal B breast cancers reveals NHERF1 as a new marker of endocrine resistance. Breast Cancer Res Treat 130 409-420, 2011.

108. Bergamaschi A, Christensen BL and Katzenellenbogen BS: Reversal of endocrine resistance in breast cancer: interrelationships among 14-3-3 , FOXM1, and a gene signature associated with mitosis. Breast Cancer Res 13: R70, 2011.

109. Glynn RW, Miller N, Mahon S and Kerin MJ: Expression levels of HER $2 /$ neu and those of collocated genes at 17q12-21, in breas cancer. Oncol Rep 28: 365-369, 2012.

110. Sotiriou C and Pusztai L: Gene-expression signatures in breast cancer. N Engl J Med 360: 790-800, 2009.

111. Campbell RA, Bhat-Nakshatri P, Patel NM, Constantinidou D, Ali S and Nakshatri H: Phosphatidylinositol 3-kinase/AKTmediated activation of estrogen receptor $\alpha$ : a new model for anti-estrogen resistance. J Biol Chem 276: 9817-9824, 2001.

112. Law JH, Habibi G, Hu K, et al: Phosphorylated insulin-like growth factor-i/insulin receptor is present in all breast cancer subtypes and is related to poor survival. Cancer Res 68 10238-10246, 2008

113. Browne BC, O'Brien N, Duffy MJ, Crown J and O'Donovan N: HER-2 signaling and inhibition in breast cancer. Curr Cancer Drug Targets 9: 419-438, 2009.

114. Foulkes WD, Smith IE and Reis-Filho JS: Triple-negative breast cancer. N Engl J Med 363: 1938-1948, 2010.

115. Rodríguez-Pinilla SM, Sarrió D, Honrado E, et al: Vimentin and laminin expression is associated with basal-like phenotype in both sporadic and BRCA1-associated breast carcinomas. J Clin Pathol 60: 1006-1012, 2007.

116. Matos I, Dufloth R, Alvarenga M, Zeferino LC and Schmitt F: p63, cytokeratin 5, and P-cadherin: three molecular markers to distinguish basal phenotype in breast carcinomas. Virchows Arch 447: 688-694, 2005.

117. Wu ZQ, Li XY, Hu CY, Ford M, Kleer CG and Weiss SJ: Canonical Wnt signaling regulates Slug activity and links epithelial-mesenchymal transition with epigenetic breast cancer 1, early onset (BRCA1) repression. Proc Natl Acad Sci USA 109: 16654-16659, 2012.

118. Agus DB, Akita RW, Fox WD, et al: Targeting ligand-activated ErbB2 signaling inhibits breast and prostate tumor growth Cancer Cell 2: 127-137, 2002.

119. Kurokawa H, Lenferink AE, Simpson JF, et al: Inhibition of HER2/neu (erbB-2) and mitogen-activated protein kinases enhances tamoxifen action against HER2-overexpressing, tamoxifen-resistant breast cancer cells. Cancer Res 60 : 5887-5894, 2000.

120. Moulder SL, Baetz T, Borges V, et al: ARRY-380, a selective HER2 inhibitor: from drug design to clinical evaluation. Mol Cancer Ther 10: abs. A143, 2011.

121. Nelson JM and Fry DW: Akt, MAPK (Erk1/2), and p38 act in concert to promote apoptosis in response to ErbB receptor family inhibition. J Biol Chem 276: 14842-14847, 2001.

122. Rabindran SK, Discafani CM, Rosfjord EC, et al: Antitumor activity of HKI-272, an orally active, irreversible inhibitor of the HER-2 tyrosine kinase. Cancer Res 64: 3958-3965, 2004.

123. Lai CJ, Bao R, Tao X, et al: CUDC-101, a multitargeted inhibitor of histone deacetylase, epidermal growth factor receptor, and human epidermal growth factor receptor 2 , exerts potent anticancer activity. Cancer Res 70: 3647-3656, 2010.

124. Hickinson DM, Klinowska T, Speake G, et al: AZD8931, an equipotent, reversible inhibitor of signaling by epidermal growth factor receptor, ERBB2 (HER2), and ERBB3: a unique agent for simultaneous ERBB receptor blockade in cancer. Clin Cancer Res 16: 1159-1169, 2010.

125. Haluska P, Carboni JM, TenEyck C, et al: HER receptor signaling confers resistance to the insulin-like growth factor-I receptor inhibitor, BMS-536924. Mol Cancer Ther 7: 2589-2598, 2008.
126. Miknis G, Wallace E, Lyssikatos J, et al: ARRY-334543, a potent, orally active small molecule inhibitor of EGFR and ErbB-2. Proc Amer Assoc Cancer Res 24: abs. 3399, 2005

127. Kalous O, Conklin D, Desai AJ, et al: Dacomitinib (PF-00299804), an irreversible Pan-HER inhibitor, inhibits proliferation of HER2-amplified breast cancer cell lines resistant to trastuzumab and lapatinib. Mol Cancer Ther 11: 1978-1987, 2012.

128. Ishikawa T, Seto M, Banno H, et al: Design and synthesis of novel human epidermal growth factor receptor 2 (HER2)/epidermal growth factor receptor (EGFR) dual inhibitors bearing a pyrrolo[3,2-d]pyrimidine scaffold. J Med Chem 54: 8030-8050, 2011.

129. Powis G, Ihle N and Kirkpatrick DL: Practicalities of drugging the phosphatidylinositol-3-kinase/Akt cell survival signaling pathway. Clin Cancer Res 12: 2964-2966, 2006.

130. Bos M, Mendelsohn J, Kim YM, Albanell J, Fry DW and Baselga J: PD153035, a tyrosine kinase inhibitor, prevents epidermal growth factor receptor activation and inhibits growth of cancer cells in a receptor number-dependent manner. Clin Cancer Res 3: 2099-2106, 1997.

131. Wilhelm SM, Dumas J, Adnane L, et al: Regorafenib (BAY 73-4506): A new oral multikinase inhibitor of angiogenic, stromal and oncogenic receptor tyrosine kinases with potent preclinical antitumor activity. Int J Cancer 129: 245-255, 2011.

132. Wilhelm SM, Carter C, Tang L, et al: BAY 43-9006 exhibits broad spectrum oral antitumor activity and targets the $\mathrm{RAF} / \mathrm{MEK} / \mathrm{ERK}$ pathway and receptor tyrosine kinases involved in tumor progression and angiogenesis. Cancer Res 64 7099-7109, 2004.

133. Falcon BL, Barr S, Gokhale PC, et al: Reduced VEGF production, angiogenesis, and vascular regrowth contribute to the antitumor properties of dual mTORC1/mTORC 2 inhibitors. Cancer Res 71: 1573-1583, 2011

134. Mendel DB, Laird AD, Xin X, et al: In vivo antitumor activity of SU11248, a novel tyrosine kinase inhibitor targeting vascular endothelial growth factor and platelet-derived growth factor receptors: determination of a pharmacokinetic/pharmacodynamic relationship. Clin Cancer Res 9: 327-337, 2003.

135. Hu-Lowe DD, Zou HY, Grazzini ML, et al: Nonclinical antiangiogenesis and antitumor activities of axitinib (AG-013736), an oral, potent, and selective inhibitor of vascular endothelial growth factor receptor tyrosine kinases $1,2,3$. Clin Cancer Res 14: 7272-7283, 2008

136. Wedge SR, Kendrew J, Hennequin LF, et al: AZD2171: a highly potent, orally bioavailable, vascular endothelial growth factor receptor-2 tyrosine kinase inhibitor for the treatment of cancer. Cancer Res 65: 4389-4400, 2005.

137. Wedge SR, Ogilvie DJ, Dukes M, et al: ZD6474 inhibits vascular endothelial growth factor signaling, angiogenesis, and tumor growth following oral administration. Cancer Res 62: 4645-4655, 2002

138. Matsui J, Funahashi Y, Uenaka T, Watanabe T, Tsuruoka A and Asada M: Multi-kinase inhibitor E7080 suppresses lymph node and lung metastases of human mammary breast tumor MDA-MB-231 via inhibition of vascular endothelial growth factor-receptor (VEGF-R) 2 and VEGF-R3 kinase. Clin Cancer Res 14: 5459-5465, 2008

139. Fletcher GC, Brokx RD, Denny TA, et al: ENMD-2076 is an orally active kinase inhibitor with antiangiogenic and antiproliferative mechanisms of action. Mol Cancer Ther 10: 126-137, 2011.

140. Strumberg D, Schultheis B, Adamietz IA, et al: Phase I dose escalation study of telatinib (BAY 57-9352) in patients with advanced solid tumours. Br J Cancer 99: 1579-1585, 2008.

141. Albert DH, Tapang P, Magoc TJ, et al: Preclinical activity of ABT-869, a multitargeted receptor tyrosine kinase inhibitor. Mol Cancer Ther 5: 995-1006, 2006.

142. Mi YJ, Liang YJ, Huang HB, et al: Apatinib (YN968D1) reverses multidrug resistance by inhibiting the efflux function of multiple ATP-binding cassette transporters. Cancer Res 70: 7981-7991, 2010.

143. Yakes FM, Chen J, Tan J, et al: Cabozantinib (XL184), a novel MET and VEGFR2 inhibitor, simultaneously suppresses metastasis, angiogenesis, and tumor growth. Mol Cancer Ther 10: 2298-2308, 2011.

144. Mordant P, Loriot Y, Leteur C, et al: Dependence on phosphoinositide 3-kinase and RAS-RAF pathways drive the activity of RAF265, a novel RAF/VEGFR2 inhibitor, and RAD001 (Everolimus) in combination. Mol Cancer Ther 9: 358-368, 2010 
145. Gendreau SB, Ventura R, Keast P, et al: Inhibition of the T790M gatekeeper mutant of the epidermal growth factor receptor by EXEL-7647. Clin Cancer Res 13: 3713-3723, 2007.

146. Turner $\mathrm{N}$ and Grose R: Fibroblast growth factor signalling: from development to cancer. Nat Rev Cancer 10: 116-129, 2010.

147. Gavine PR, Mooney L, Kilgour E, et al: AZD4547: an orally bioavailable, potent, and selective inhibitor of the fibroblast growth factor receptor tyrosine kinase family. Cancer Res 72: 2045-2056, 2012.

148. García-Echeverría C, Pearson MA, Marti A, et al: In vivo antitumor activity of NVP-AEW541-A novel, potent, and selective inhibitor of the IGF-IR kinase. Cancer Cell 5: 231-239, 2004.

149. Sabbatini P, Rowand JL, Groy A, et al: Antitumor activity of GSK1904529A, a small-molecule inhibitor of the insulin-like growth factor-I receptor tyrosine kinase. Clin Cancer Res 15 : 3058-3067, 2009.

150. Mulvihill MJ, Cooke A, Rosenfeld-Franklin M, et al: Discovery of OSI-906: a selective and orally efficacious dual inhibitor of the IGF-1 receptor and insulin receptor. Future Med Chem 1: 1153-1171, 2009.

151. Wen B, Deutsch E, Marangoni E, et al: Tyrphostin AG 1024 modulates radiosensitivity in human breast cancer cells. Br J Cancer 85: 2017-2021, 2001

152. Sabbatini P, Korenchuk S, Rowand JL, et al: GSK1838705A inhibits the insulin-like growth factor-1 receptor and anaplastic lymphoma kinase and shows antitumor activity in experimental models of human cancers. Mol Cancer Ther 8: 2811-2820, 2009.

153. Simoncini T, Hafezi-Moghadam A, Brazil DP, Ley K, Chin WW and Liao JK: Interaction of oestrogen receptor with the regulatory subunit of phosphatidylinositol-3-OH kinase. Nature 407: 538-541, 2000.

154. Migliaccio A, Castoria G, Di Domenico M, et al: Steroid-induced androgen receptor-oestradiol receptor $\beta$-Src complex triggers prostate cancer cell proliferation. EMBO J 19: 5406-5417, 2000

155. Junttila TT, Akita RW, Parsons K, et al: Ligand-independent HER2/HER3/PI3K complex is disrupted by trastuzumab and is effectively inhibited by the PI3K inhibitor GDC-0941. Cancer Cell 15: 429-440, 2009.

156. Yu K, Toral-Barza L, Shi C, Zhang WG and Zask A: Response and determinants of cancer cell susceptibility to PI3K inhibitors: combined targeting of PI3K and Mek1 as an effective anticancer strategy. Cancer Biol Ther 7: 307-315, 2008.

157. Smirnova T, Zhou ZN, Flinn RJ, et al: Phosphoinositide 3-kinase signaling is critical for ErbB3-driven breast cancer cell motility and metastasis. Oncogene 31: 706-715, 2012

158. Knight SD, Adams ND, Burgess JL, et al: Discovery of GSK2126458, a highly potent inhibitor of PI3K and the mammalian target of rapamycin. ACS Med Chem Lett 1: 39-43, 2010.

159. Mallon R,HollanderI,Feldberg L, et al: Antitumor efficacy profile of PKI-402, a dual phosphatidylinositol 3-kinase/mammalian target of rapamycin inhibitor. Mol Cancer Ther 9: 976-984, 2010.

160. Sutherlin DP, Bao L, Berry M, et al: Discovery of a potent, selective, and orally available class I phosphatidylinositol 3-kinase (PI3K)/mammalian target of rapamycin (mTOR) kinase inhibitor (GDC-0980) for the treatment of cancer. J Med Chem 54: 7579-7587, 2011.

161. Venkatesan AM, Dehnhardt CM, Delos Santos E, et al: Bis(morpholino-1,3,5-triazine) derivatives: potent adenosine 5'-triphosphate competitive phosphatidylinositol-3-kinase/ mammalian target of rapamycin inhibitors: discovery of compound 26 (PKI-587), a highly efficacious dual inhibitor. J Med Chem 53: 2636-2645, 2010.
162. Rhodes N, Heerding DA, Duckett DR, et al: Characterization of an Akt kinase inhibitor with potent pharmacodynamic and antitumor activity. Cancer Res 68: 2366-2374, 2008.

163. Grimshaw KM, Hunter LJ, Yap TA, et al: AT7867 is a potent and oral inhibitor of AKT and p70 S6 kinase that induces pharmacodynamic changes and inhibits human tumor xenograft growth. Mol Cancer Ther 9: 1100-1110, 2010.

164. Meuillet EJ, Zuohe S, Lemos R, et al: Molecular pharmacology and antitumor activity of PHT-427, a novel Akt/phosphatidylinositide-dependent protein kinase 1 pleckstrin homology domain inhibitor. Mol Cancer Ther 9: 706-717, 2010.

165. Lu CH, Wyszomierski SL, Tseng LM, et al: Preclinical testing of clinically applicable strategies for overcoming trastuzumab resistance caused by PTEN deficiency. Clin Cancer Res 13: 5883-5888, 2007.

166. Feldman RI, Wu JM, Polokoff MA, et al: Novel small molecule inhibitors of 3-phosphoinositide-dependent kinase-1. J Biol Chem 280: 19867-19874, 2005.

167. Cully M, You H, Levine AJ and Mak TW: Beyond PTEN mutations: the PI3K pathway as an integrator of multiple inputs during tumorigenesis. Nat Rev Cancer 6: 184-192, 2006.

168. Shor B, Zhang WG, Toral-Barza L, et al: A new pharmacologic action of CCI-779 involves FKBP12-independent inhibition of mTOR kinase activity and profound repression of global protein synthesis. Cancer Res 68: 2934-2943, 2008.

169. Rivera VM, Squillace RM, Miller D, et al: Ridaforolimus (AP23573; MK-8669), a potent mTOR inhibitor, has broad antitumor activity and can be optimally administered using intermittent dosing regimens. Mol Cancer Ther 10: 1059-1071, 2011

170. Yuan J, Mehta PP, Yin MJ, et al: PF-04691502, a potent and selective oral inhibitor of PI3K and mTOR kinases with antitumor activity. Mol Cancer Ther 10: 2189-2199, 2011.

171. Chresta CM, Davies BR, Hickson I, et al: AZD8055 is a potent, selective, and orally bioavailable ATP-competitive mammalian target of rapamycin kinase inhibitor with in vitro and in vivo antitumor activity. Cancer Res 70: 288-298, 2009.

172. Bhagwat SV, Gokhale PC, Crew AP, et al: Preclinical characterization of OSI-027, a potent and selective inhibitor of mTORC1 and mTORC2: distinct from rapamycin. Mol Cancer Ther 10: 1394-1406, 2011.

173. Wallin JJ, Edgar KA, Guan J, et al: GDC-0980 is a novel class I $\mathrm{PI} 3 \mathrm{~K} / \mathrm{mTOR}$ kinase inhibitor with robust activity in cancer models driven by the PI3K pathway. Mol Cancer Ther 10: 2426-2436, 2011.

174. Yu K, Toral-Barza L, Shi C, et al: Biochemical, cellular, and in vivo activity of novel ATP-competitive and selective inhibitors of the mammalian target of rapamycin. Cancer Res 69: 6232-6240, 2009

175. Guichard SM, Howard Z, Heathcote D, et al: AZD2014, a dual mTORC1 and mTORC2 inhibitor is differentiated from allosteric inhibitors of mTORC1 in $\mathrm{ER}^{+}$breast cancer. Cancer Res 72: abs. 917, 2012.

176. Liu Q, Thoreen C, Wang J, Sabatini D and Gray NS: mTOR mediated anti-cancer drug discovery. Drug Discov Today Ther Strateg 6: 47-55, 2009.

177. Hawkins W, Mitchell C, McKinstry R, et al: Transient exposure of mammary tumors to PD184352 and UCN-01 causes tumor cell death in vivo and prolonged suppression of tumor regrowth. Cancer Biol Ther 4: 1275-1284, 2005.

178. Ohren JF, Chen H, Pavlovsky A, et al: Structures of human MAP kinase kinase 1 (MEK1) and MEK2 describe novel noncompetitive kinase inhibition. Nat Struct Mol Biol 11: 1192-1197, 2004. 